\title{
The Roles of Reproduction, Survival, and Territoriality in the Seasonal Dynamics of Clethrionomys gapperi Populations
}

\author{
M. R. PERRIN ${ }^{1}$
}

Perrin M. R., 1979: The roles of reproduction, survival and territoriality in the seasonal dynamics of Clethrionomys gapperi populations. Acta theriol., 24, 35: 477-500 [With 6 Tables \& 14 Figs.]

An intensive study has been made of the population ecology of the redbacked vole Clethrionomys gapperi (V i gor s, 1830) inhabiting black spruce (Picea mariana) forest in southeastern Manitoba. The roles of reproduction, survival and territoriality have been examined in relation to the seasonal dynamics of this vole. Peak densities occurred in 1974 after an increase phase in 1973. During the winter of $1974 / 5$ a crash or type $M$ decline occurred, which was temporally associated with extreme climatic conditions. Overwintered females produced approximately $70 \%$ of the litters during the breeding season, and only females from the first cohort produced litters during the year of their birth. First litters were synchronized, probably by daylength, and a second peak in litter production occurred in late summer. Litter size was large, which might be an adaptation to increase productivity, since the breeding season was short. The breeding season appeared to be longer during the increase than the peak phase; winter breeding was not observed. Winter survival in $1973 / 4$ was superior to that during the 1974 breeding season and overwintered males survived longer than overwintered females during the breeding season. Juvenile survival was poor and males survived less well than females, but no large differences in survival oocurred between cohorts during 1974. No significant differences occurred in the size of home ranges either between sexes or between seasons. Females held exclusive territories in summer but males occupied overlapping ranges, the centers of which often shifted after snow-melt. The establishment of young females in territories was probably affected by the survival of overwintered females, population density, and habitat suitability. It is tentatively suggested that the natural regulation of C. gapperi is based on spacing behaviour through aggression, with weather as an ancillary limiting factor, and food supply as the ultimate controlling factor.

[Environmental Res. Branch, Whiteshell Nuclear Res., Establishment, Atomic Energy of Canada Ltd., Pinawa, Manitoba, Canada, ROE 1LO],

\section{INTRODUCTION}

There have been few intensive studies of the population biology of the redbacked vole (Clethrionomys gapperi) (B u t s c h, 1954; E 11 i o t t, 1969) but several European Clethrionomys species have been thoroughly investigated ( $\mathrm{Z}$ e j d a, 1961, 1964, 1967; $\mathrm{K}$ a l e l a, 1957; $\mathrm{K}$ a i k u s a $\mathrm{lo}$,

1 Present address: Dept. Zool. and Entomol., Rhodes Univ., P.O. Box 94, Grahamstown, 6140, South Africa. 
1972; K o s h kina, 1965; M a rkov et al. 1972 a, b). Hence, this study was designed to examine the roles of reproduction, survival, and territoriality in the seasonal dynamics of C. gapperi and to relate changes in numbers to changes in body composition (P e r r in, 1979) and behaviour ( $\mathrm{P}$ e r r i n, in prep).

The study encompassed increase and peak density years and explored some aspects of a winter decline. Specific objectives of the study were to determine the length of the breeding season and the intensity of breeding; litter size; the age and caste structure of the breeding population; differences in survival between seasons, sexes, and age classes; the level of juvenile recruitment in terms of cohort survival; changes in the spatial distribution between sexes and seasons; and the occurrence of territoriality in C. gapperi.

\section{METHODS}

The population of C. gapperi studied was situated $3 \mathrm{~km}$ northeast of the Whiteshell Nuclear Research Establishment at Pinawa, southeastern Manitoba, in black spruce (Picea mariana) forest.

A rectangular 1.89 ha grid was established in forest bordered by an open cutline on the east. North of the grid, black spruce was replaced by birch (Betula papyrifera) and aspen (Populus tremuloides). Spruce surrounded the western and southern boundaries, but dry forest was replaced by wet bog, where larch (Larix iaricina) appeared. Sphagnum was common throughout the grid and labrador tea (Ledum groenlandicum) was plentiful except under dense spruce canopies and in boggy areas. The commonest herbs (Vaccinium oxycoccos, V. vitis-idaea, Cornus canadensis, Petasites sagittatus, Gaultheria hispidula and Rubus pubescens) were widely distributed, but were more abundant in the north, and on the eastern margin of the grid (Fig. 13).

Live-traps were set biweekly for two consecutive nights on a $12 \times 7$ station grid, with $15 \mathrm{~m}$ spacing, from November 1973 to December 1974. A plywood shelter (I verson \& Turner, 1969) at each station allowed low-mortality winter trapping. Whole oats were used as bait, and carrots and wood shavings were placed inside the nest-box of the Longworth traps to improve vole survival. Traps containing animals were taken to the laboratory by approximately $10.00 \mathrm{~h}$ each morning. The vole's capture location, toe-clip number, sex, reproductive condition, weight and age class were recorded. (Juveniles were sexually immature individuals weighing $\leqslant 18 \mathrm{~g}$; sub-adults were $>18 \mathrm{~g}$ but sexually immature; and adults were $>18 \mathrm{~g}$ and sexually mature.) Voles used in behaviour tests (Perrin in prep) were held overnight in the laboratory and released at their capture location the following morning. This population provided data on behaviour, home range, mobility, reproduction, survival and density.

Snap-trap lines, with stations at $15 \mathrm{~m}$ intervals, were set in nearby black spruce forest on alternate weeks to the grid trapping over the same period. Two Museum Special snap-traps baited with peanut-butter were set for four consecutive nights and checked daily. In winter, holes were dug in the snow and traps were placed on the ground. All voles were weighed, measured, and their reproductive organs were removed,-fixed in formalin prior to weighing, and 
examined later to determine litter size or testis activity. The lower jaw was removed so that the first molar could be extracted and the vole aged on the length of the tooth root (P e rrin, 1978). Young voles, that had not developed molar roots, were aged on the basis of body weight. Stomach contents were removed for examination and carcasses were analysed to determine their composition (P e r rin in press).

Density was estimated by direct enumeration, since numbers were low and the probability of capture was very high $(84 \%)$. Survival was estimated on a biweekly basis by the technique of Christian (see Davis, 1956). Survival of individuals born during the same time period, i.e., a cohort, was considered for each sex separately. First cohort voles were those born before 1 June, second cohort between 1 June and $15 \mathrm{July}$, and third cohort after $15 \mathrm{July}$. The minimum (polygon) area method was used to describe summer and winter home ranges (Stickel, 1954) for individuals caught five or more times per season. Long distance movements, that is those greater than the distance between adjacent trap stations but outside an established home range, were recorded. If the individual was captured more than once at this position, the area was included within the home range area. Irregularly and/or infrequently trapped young voles were called stransients * whereas adults with established home ranges were called sresidents«. The occurrence of births in 1973 was based on the aging of adults caught late in 1973 and throughout 1974 by backdating to the day of birth (Perrin, 1978). The distribution of 1974 births was based on the autopsies of snap-trapped pregnant females and from live-trapped voles on the gird. The aging of regularly snap-trapped voles provided information on population age structure. Measurements of snow cover and subnivean temperatures were recorded in winter.

\section{RESULTS}

During the study a marked seasonal change in density was observed (Fig. 1) with peak numbers occurring in August. Numbers were stable throughout the winter of $1973 / 4$ but declined drastically late in 1974 . Input (natality plus immigration) and output (mortality plus emigration) were low during the $1973 / 4$ winter, but by June input exceeded output, and numbers increased throughout July. In August and September, some turnover continued but numbers were approximately stable. The population then declined to the end of the study in December. Only three voles were captured when the grid was intensively retrapped in May 1975.

There were 666 captures of 149 individual voles during the study with 14 trap deaths, which represents $9.1 \%$ mortality. The overall probability of recapture was very high $(0.84 \pm 0.002)$ and there was little difference between sexes and seasons (Fig. 2).

All overwintered males were sexually mature by mid-March (Table 1). although maximum testis weights were not reached until the end of May (Fig. 3). Overwintered females matured by mid-April (Table 1), and like the males remained potent until death later in summer. Not 


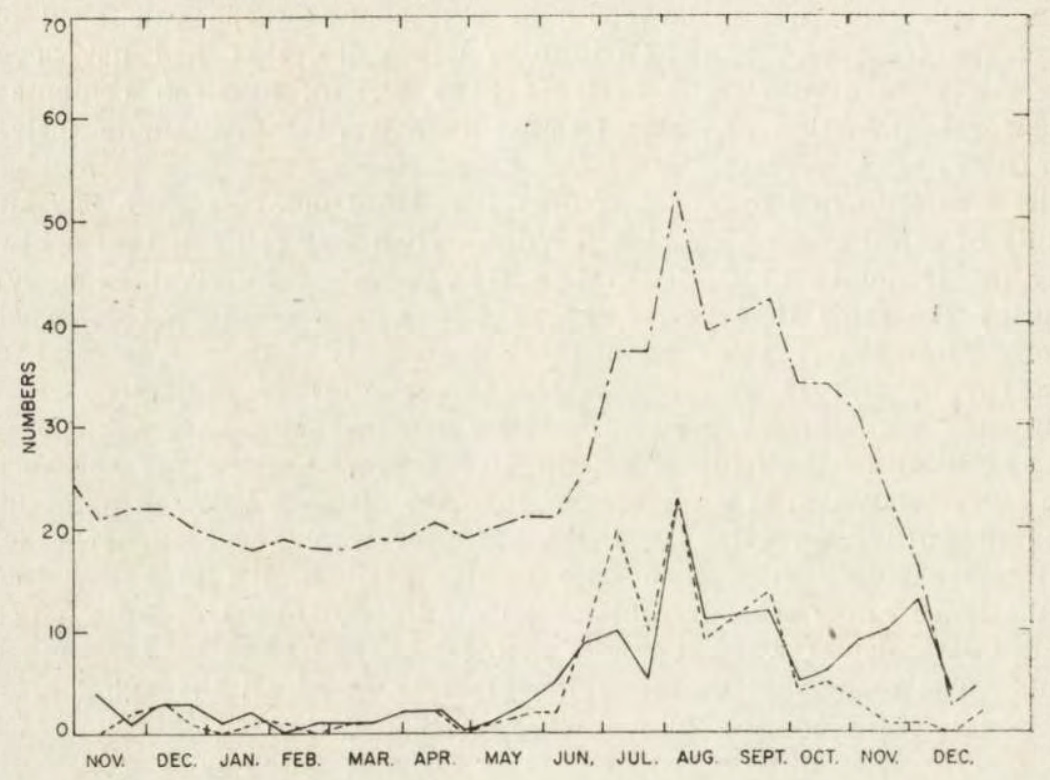

Fig. 1. Numbers of C. gapperi inhabiting the spruce-forest live-grid.

Total numbers are indicated separately (-., ) from original captures $(--\rightarrow$ (natality plus immigration), and final captures (- $($ ) (mortality plus emigration).

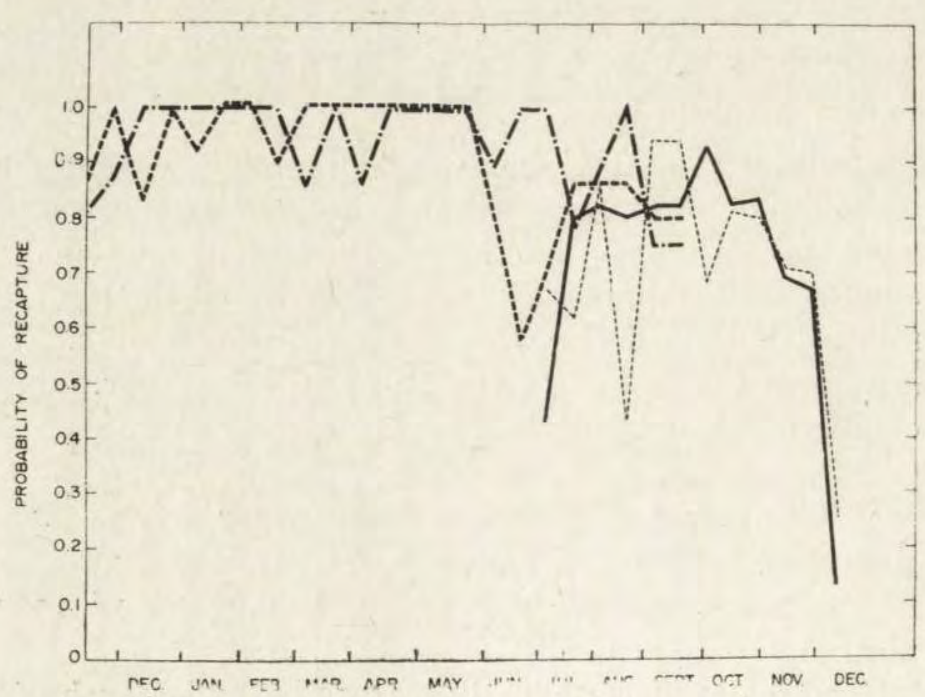

Fig. 2. Probability of recapture of C. gapperi inhabiting the spruce-forest live-grid. Overwintered males (_- $)$ ) and females (-...) are indicated separately from young males (...) and females (-). 
all sub-adult voles attained sexual maturity in their summer of birth (Table 1), although some young females produced litters, as indicated by uterus weight (Fig. 4). Thus a large proportion of the population was reproductively active from April to August inclusively. The overall sex ratio from live-trapped voles was $100 \hat{\delta}: 81$, with excess males being caught in mid-summer and during the winter decline (1974). The higher occurrence of males in summer was temporally associated with breeding, when females may have been restricted to a nestsite during lactation.

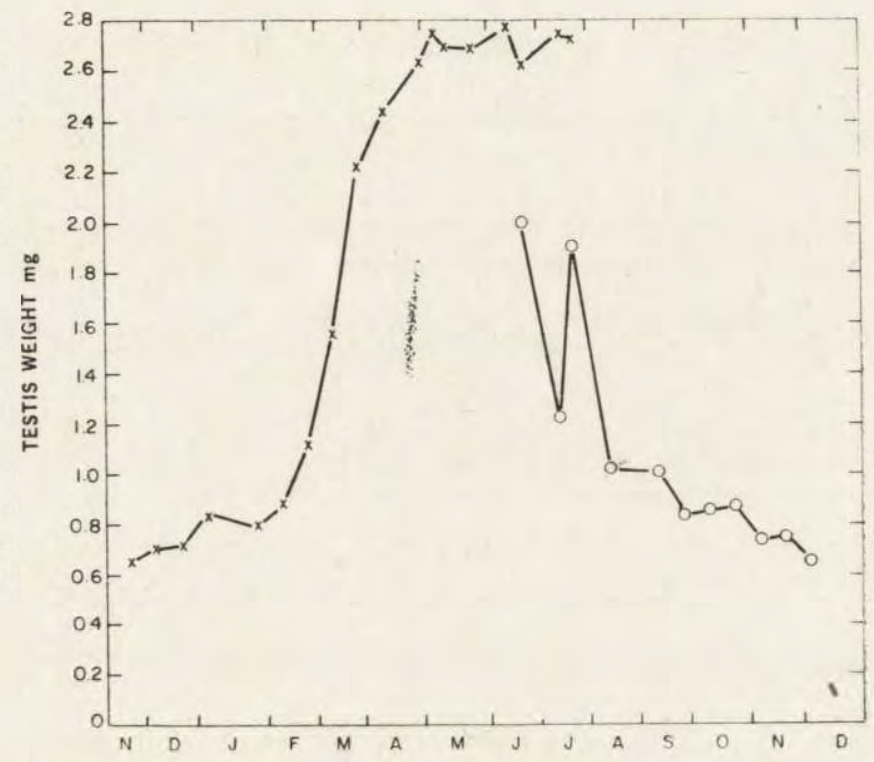

Fig. 3. Mean testis weight of overwintered $(X)$ and young $(O)$ male $C$. gapperi.

Births on the grid occurred from the first week of April until the third week of August during 1974 (Fig. 5); young of the year produced their first litters in the first week of July. Seven overwintered females produced a minimum of eighteen litters during 1974 and six young females produced a further nine litters. Ten litters were born in traps, with a mean litter size of $6.0 \pm 1.68$. Thus an estimated minimum of 162 voles were born on the grid, of which $98(60 \%)$ different individuals $(58 \delta 40$ ) $)$ were captured as sub-adults. Of the 50 pregnant mice taken in snap-traps, 35 were overwintered adults $(70 \%)$. The mean litter size of the overwintered females $(5.91 \pm 0.25)$ was not significantly larger than that of young of the year females $(5.35 \pm 0.25)$. Thus, in both samples, more than two thirds of the voles born were derived from overwintered females. Young were born over a four month period, 
with maximum production occurring late in May and late in July (Fig. 5). Since all of the voles snap-trapped in 1973/4 were aged (P e rri n, 1978) it was possible to predict approximate birth dates for 1973 by backdating. Births appeared to be normally distributed throughout the year (Fig. 5).

A correlation analysis was performed between litter size, and (1) maternal (lean dry) weight, (2) maternal age (overwintered adults only), and (3) time from the onset of breeding, for the snap-trapped voles (Table 2). There was a significant positive correlation between litter

Table 1

Changes in the proportion of the live trapped population of $C$. gapperi which was sexually mature during the 1974 breeding season.

\begin{tabular}{|c|c|c|c|c|c|c|c|}
\hline \multirow[b]{2}{*}{ Date } & \multicolumn{2}{|c|}{ Overwintered Adults } & \multicolumn{2}{|c|}{$\frac{\text { Summer-born }}{\% \text { Mature }}$} & \multicolumn{2}{|c|}{ Whole Population } & \multirow[b]{2}{*}{$\begin{array}{l}\text { Total } \\
\mathrm{N}\end{array}$} \\
\hline & Males & $\begin{array}{l}\text { Mature } \\
\text { Females }\end{array}$ & $\begin{array}{l}\% \\
\text { Males }\end{array}$ & $\begin{array}{l}\text { Mature } \\
\text { Females }\end{array}$ & $\begin{array}{l}\quad \% \\
\text { Males }\end{array}$ & $\begin{array}{l}\text { Mature } \\
\text { Females }\end{array}$ & \\
\hline $20 \mathrm{Feb}$ & 0.0 & 0.0 & - & - & 0.0 & 0.0 & 17 \\
\hline $5 \mathrm{Mar}$ & 22.2 & 22.2 & - & - & 22.2 & 22.2 & 18 \\
\hline $19 \mathrm{Mar}$ & 100.0 & 33.3 & - & - & 100.0 & 33.3 & 18 \\
\hline $2 \mathrm{Apr}$ & 100.0 & 85.7 & - & - & 100.0 & 85.7 & 16 \\
\hline $16 \mathrm{Apr}$ & 100.0 & 100.0 & - & - & 100.0 & 100.0 & 18 \\
\hline $30 \mathrm{Apr}$ & 100.0 & 100.0 & - & - & 100.0 & 100.0 & 14 \\
\hline 14 May & 100.0 & 100.0 & - & - & 100.0 & 100.0 & 18 \\
\hline 28 May & 100.0 & 100.0 & - & - & 100.0 & 100.0 & 19 \\
\hline 11 Jun & 100.0 & 100.0 & - & - & 100.0 & 100.0 & 19 \\
\hline 20 Jun & 100.0 & 100.0 & 100.0 & 57.1 & 100.0 & 78.6 & 24 \\
\hline $9 \mathrm{Jul}$ & 100.0 & 100.0 & 40.0 & 55.5 & 60.9 & 73.3 & 38 \\
\hline $23 \mathrm{Jul}$ & 100.0 & 100.0 & 71.4 & 77.8 & 65.0 & 84.6 & 33 \\
\hline 6 Aug & 100.0 & 100.0 & 34.8 & 68.8 & 46.4 & 73.7 & 47 \\
\hline 20 Aug & 100.0 & 0.0 & 25.0 & 53.8 & 52.6 & 53.8 & 32 \\
\hline $17 \mathrm{Sep}$ & 0.0 & 0.0 & 19.2 & 16.7 & 19.2 & 16.7 & 32 \\
\hline 1 Oct & 0.0 & 0.0 & 0.0 & 0.0 & 0.0 & 0.0 & 30 \\
\hline
\end{tabular}

Males were considered sexually mature if they possessed scrotal testes and females if they possessed perforate vaginas, or were pregnant or lactating.

size and lean dry weight, but not with the other parameters examined.

The age structure shown in Figure 6 was determined from the snaptrapped sample but may be indicative of changes that occurred in the nearby grid population. Voles of November and December 1973 were younger than those of the same months of 1974. This suggests that either recruitment took place from different cohorts of young, or that there was a shift in the timing of breeding. From June through October two distinct age classes were present, those of the overwintered population and the new summer population. The single winter age class became progressively older, and condensed in early summer by the loss of its youngest and oldest members.

Survival was good during the 1974 winter (Fig. 7). During the breed- 


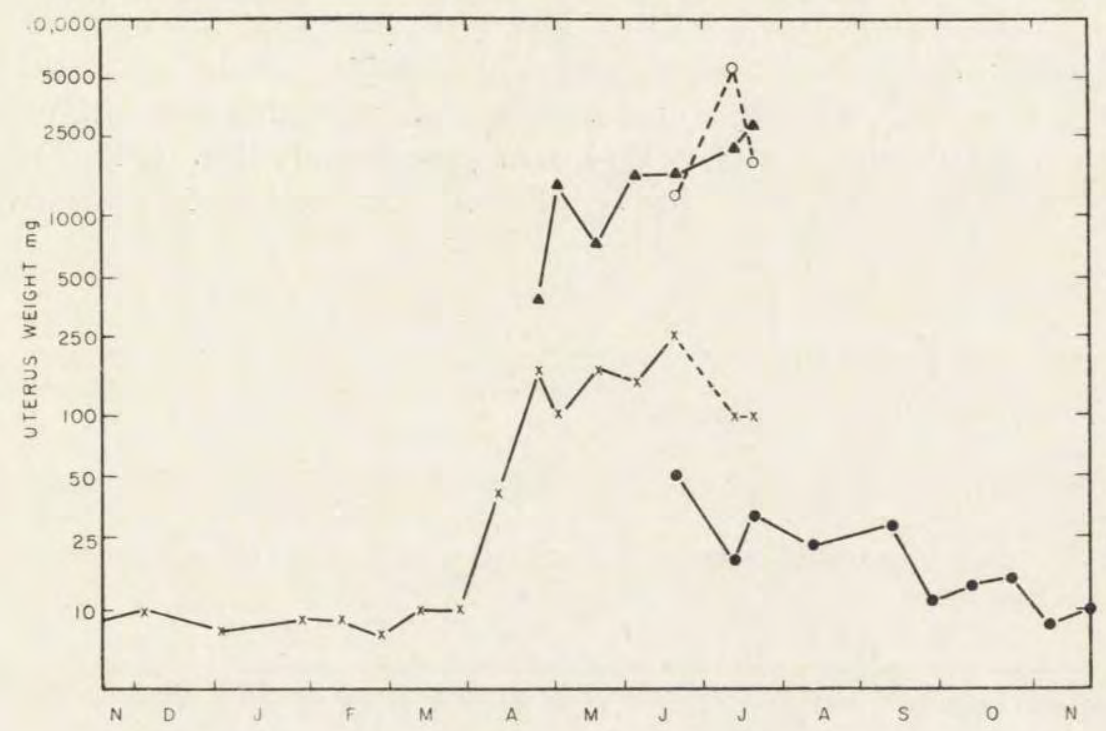

Fig. 4. Mean uterus weight (including embryos) of female C. gapperi. Pregnant, overwintered $(\boldsymbol{\Delta})$ and young $(O)$ females, are indicated separately from nonpregnant, overwintered (x) and young $(\bullet)$ females.

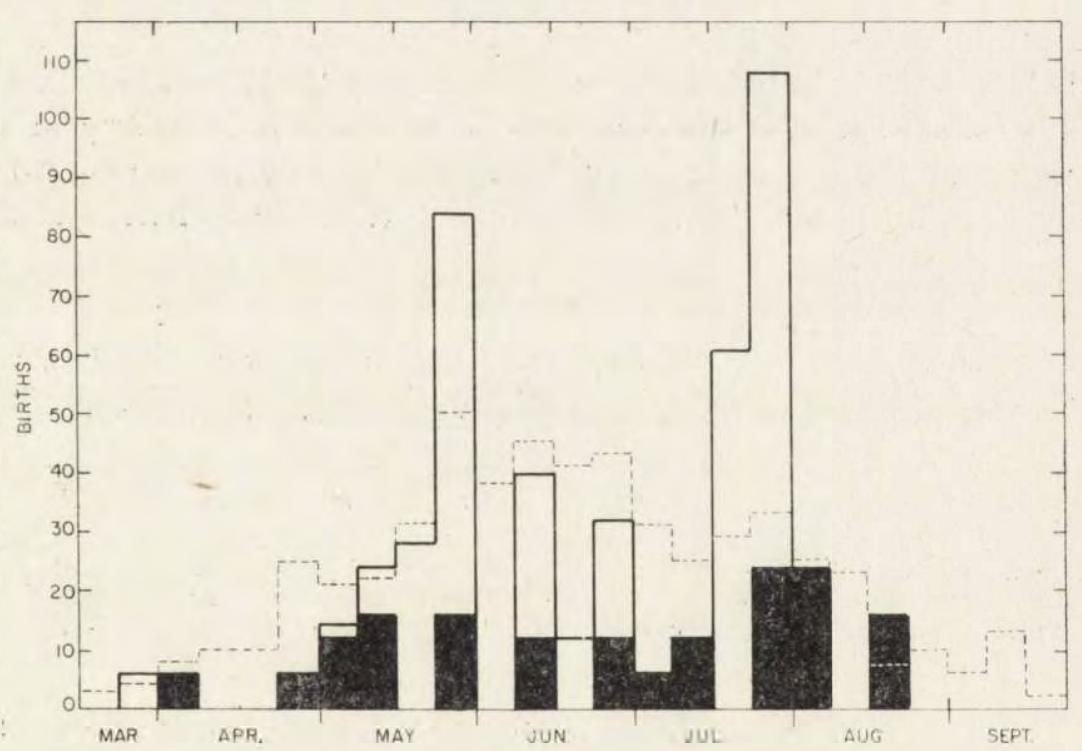

Fig. 5. The occurrence of births during the 1974 breeding season.

Numbers born on the live-trapped grid (shaded) were estimated from the product of the number of pregnant females and mean litter size. Numbers born on the snap-trap lines (unshaded) were estimated from autopsies. The timing of births during 1973 (dashed) was based on the ageing and back-dating of individual C. gapperi snap-trapped during 1973 (P e r ri n, 1978). 
ing season, overwintered females survived less well than males, but mortality was highest in young voles, particularly males. The survival of males during autumn 1973 was high, whereas the survival of subadult males during summer 1974 was precariously low (Fig. 8). This is suggestive of periods of heavy juvenile and sub-adult mortality in

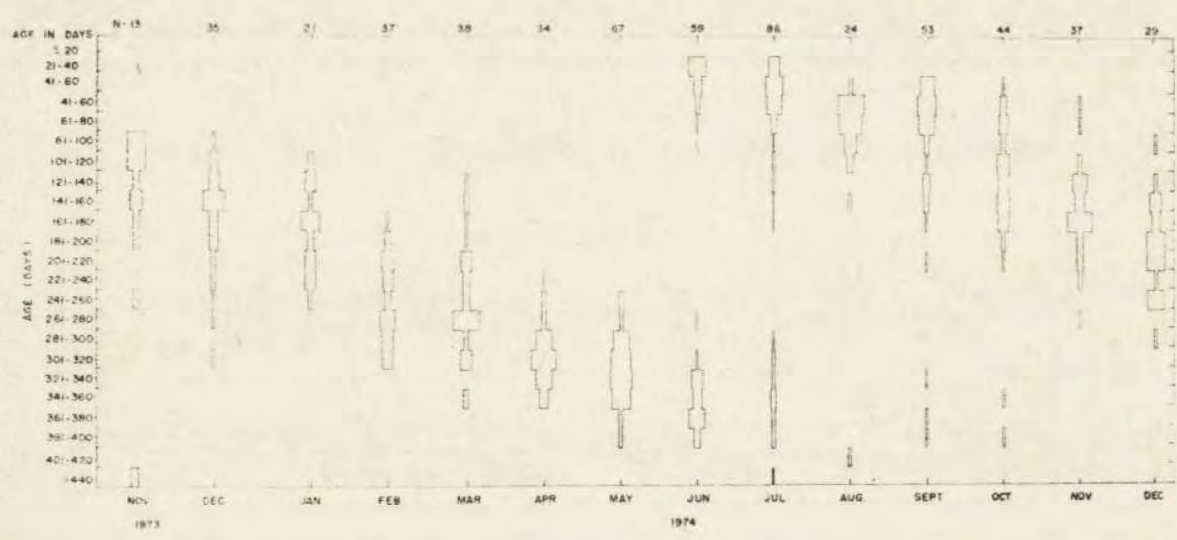

Fig. 6. Age structure of the snap-trapped C. gapperi population. Ageing was based on molar tooth root-length.

the breeding season being followed by increased survivorship of older individuals during autumn. Hence, a more detailed examination was made of cohort survival for each sex independently. Mortality of males was high, but there was little difference between cohorts (Fig. 9). The number born into each cohort was approximately equivalent, and there-

Table 2

Correlation coefficients between litter size and 1) lean dry weight, 2) age, and 3) time (from the onset of the breeding season), their significance, and the proportion of the variation explained $\left(r^{2}\right)$.

\begin{tabular}{lcccc}
\hline & $\boldsymbol{r}$ & $\boldsymbol{r}^{2}$ & $\mathrm{~N}$ & $\boldsymbol{P}$ \\
\hline Lean dry weight & 0.55 & 0.30 & 50 & 0.01 \\
Age (overwintered voles only) & 0.20 & 0.04 & 30 & N.S. \\
Time (from the onset of breeding) & 0.06 & - & 50 & N.S.
\end{tabular}

fore late-born cohorts would have formed a larger proportion of the winter population. The first females cohort suffered heavy mortality $6-8$ weeks after first capture, (Fig. 10) but the few that survived gained territories. The second cohort suffered fewer sub-adult losses and formed a considerable part of the winter population. The third cohort survived well for 10 weeks but then all were lost by sudden mortality. Many 
of the third cohort voles were born to the first cohort females because of the heavy mortality to overwintered females.

Table 3

Means and standard errors for the home range areas $\left(\mathrm{m}^{2}\right)$ (area of minimum polygon, $\mathrm{St}$ i $\mathrm{c} \mathrm{kel}$ 1, 1954) of C. gapperi. There were no significant differences, according to $t$ tests between the mean values for sex or season.

\begin{tabular}{lcc}
\hline \multicolumn{1}{c}{ Season } & Males, $\mathrm{N}=16$ & Females, $\mathrm{N}=12$ \\
\hline Summer & $753 \pm 217$ & $523 \pm 129$ \\
Winter & $859 \pm 173$ & $731 \pm 135$ \\
Combined & $1047 \pm 267$ & $844 \pm 107$ \\
\hline
\end{tabular}

Each individual was captured more than five times during each season.

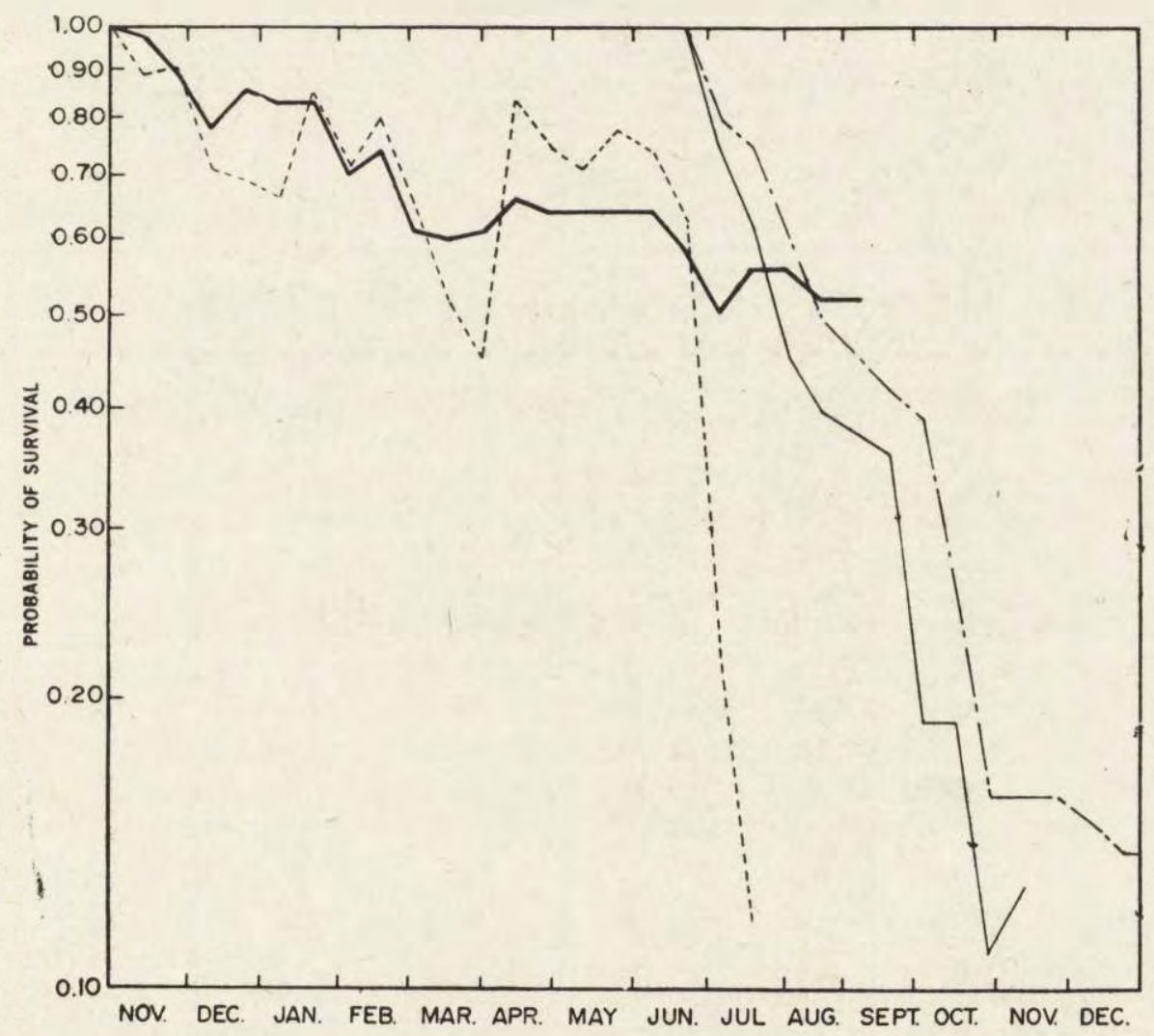

Fig. 7. Accumulative probability of survival until the next trapping period, of the live trapped $C$. gapperi population.

Overwintered males (- $\longrightarrow$ and females (- - ) are indicated separately from young males $(\longrightarrow)$ and females (-...). 
Horne ranges of males were not significantly larger than those of females at either season (Table 3), but ranges were generally larger in winter than in summer, and larger in males than females because of shifts in home range occupation following snowmelt. Long-distance movements occurred largely in summer and were typical of young transient voles rather than adult residents. The mean long-distance mo-

\section{Table 4}

Percentage of home range overlap in different seasons. Numbers in parentheses refer to the number of occupied territories.

\begin{tabular}{|c|c|c|c|}
\hline Sex & Winter $1973 / 4$ & $\begin{array}{l}\text { Spring-summer } 1974 \\
\text { (Overwintered adults) }\end{array}$ & $\begin{array}{l}\text { Summer-autumn } 1974 \\
\text { (Young of the year) }\end{array}$ \\
\hline Males & 90 & 93 & 88 \\
\hline Females & 73 & $0(6)$ & $15(13)$ \\
\hline
\end{tabular}

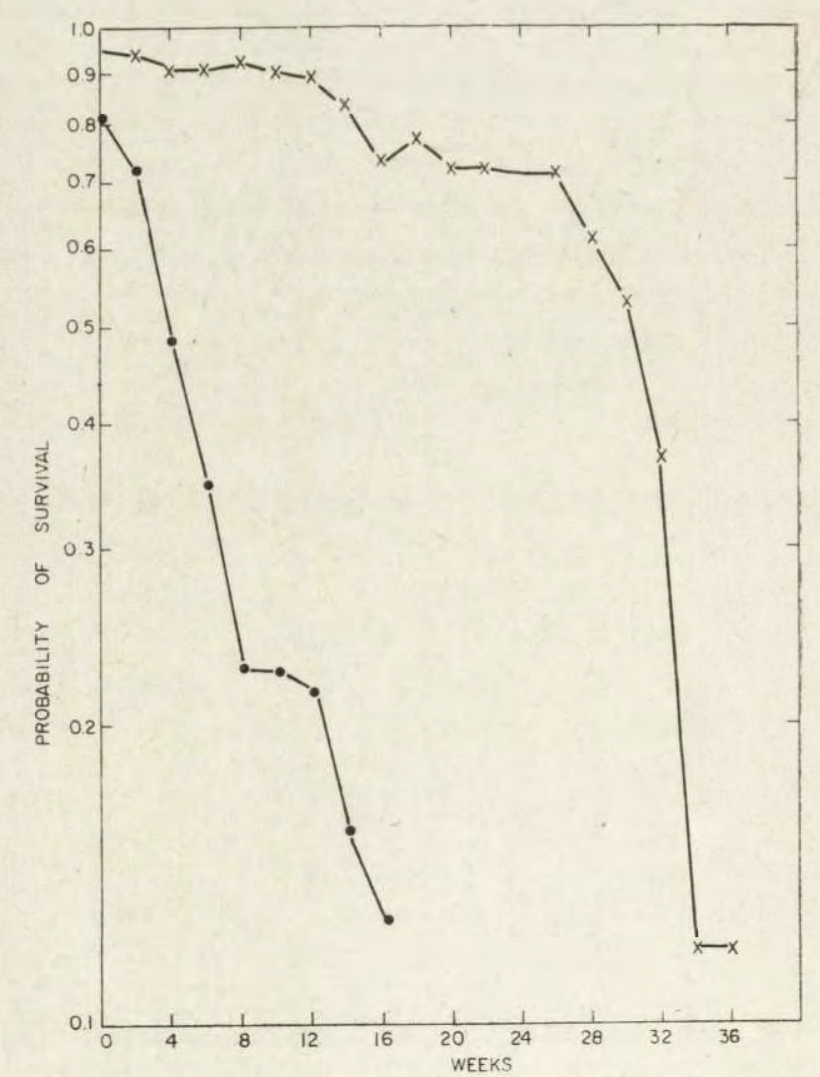

Fig. 8. Accumulative probability of survival until the next trapping period, of young male C. gapperi following the first capture during the 1974 summer or, the autumn of $1973(\mathrm{x})$, when the study was initiated. 
vement of transients $(60.5 \pm 1.9 \mathrm{~m})$ was significantly greater than that of residents $(28.3 \pm 1.9 \mathrm{~m})$.

Considerable overlapping of male home ranges occurred throughout the year, but female ranges overlapped only during winter (Table 4). Thus female ranges were spatially exclusive for both overwintered adult (Fig. 11) and young of the year (Fig. 12) during the breeding season

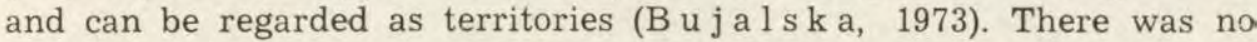

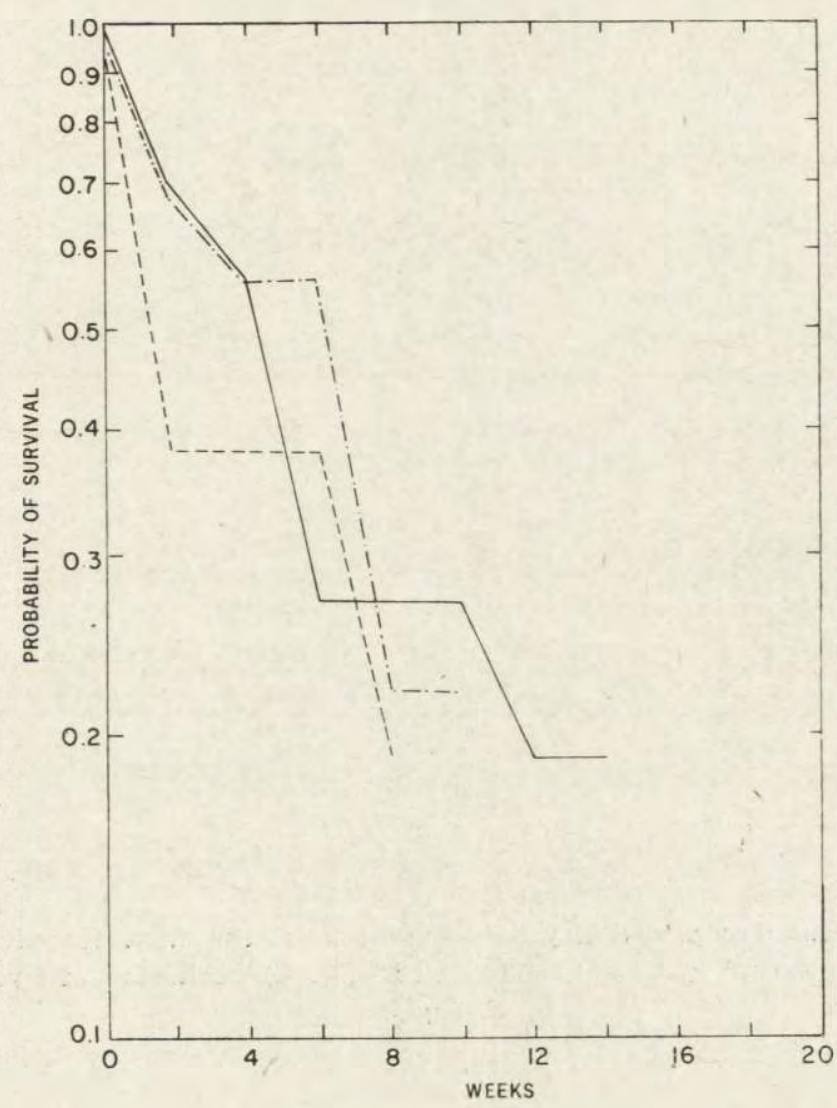

Fig. 9. Accumulative probability of survival until the next trapping period, for the first (-), second (- - ) and third (-., ) cohorts of young male C. gapperi.

temporal overlap of female territories either within an age class or between age classes (Table 4). There was a greater number of territories in autumn (13) than spring (6). The autumn territories were smaller in area and were occupied by young of the year. The pattern of distributions became more complex during the breeding season because of recruitment of young, increased mobility of males, and high levels of 
mortality, but the pattern of male ranges and female territories persisted. Home ranges of males and females overlapped extensively each season, but not all parts of the grid were utilized equally and some

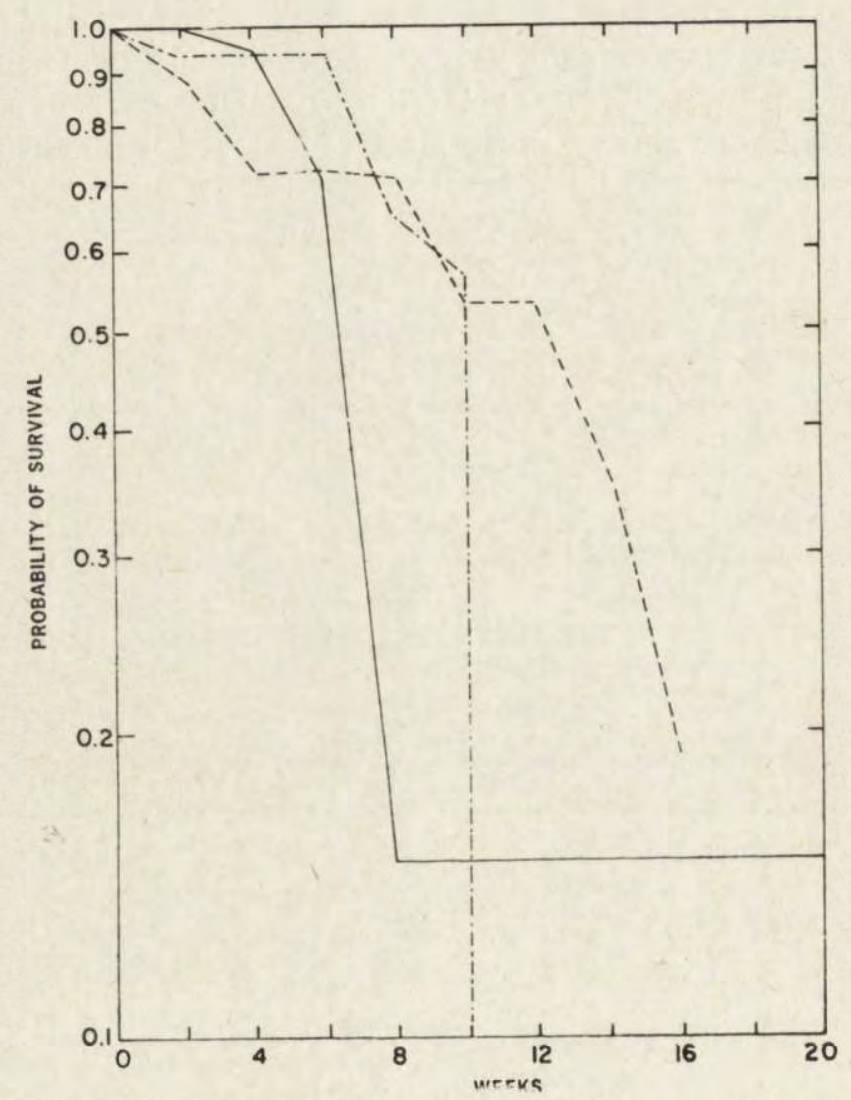

Fig. 10. Accumulative probability of survival until the next trapping period, for first (-), second (- - ), and third (-., ) cohorts of young female C. gapperi.

Table 5

Turnover of female territories.

\begin{tabular}{lccccc}
$\begin{array}{c}\text { Vole } \\
\text { Number }\end{array}$ & $\begin{array}{c}\text { Habitat } \\
\text { Class }\end{array}$ & $\begin{array}{c}\text { Area of } \\
\text { territory }\left(\mathrm{m}^{2}\right)\end{array}$ & $\begin{array}{c}\text { Date of } \\
\text { last capture }\end{array}$ & $\begin{array}{c}\text { Replaced by } \\
\text { vole number }\end{array}$ & $\begin{array}{c}\text { Date of } \\
\text { first capture }\end{array}$ \\
\hline 12 & 1 & 225 & $23 \mathrm{Jul}$ & 112 & $23 \mathrm{Jul}$ \\
18 & 1 & 225 & $28 \mathrm{May}$ & 161 & $6 \mathrm{Aug}$ \\
21 & 4 & 900 & $9 \mathrm{Jul}$ & 124 & $9 \mathrm{Jul}$ \\
33 & 1 & 225 & $23 \mathrm{Jul}$ & Vacant & - \\
34 & 3 & 450 & $6 \mathrm{Aug}$ & Vacant & - \\
37 & 5 & 550 & $6 \mathrm{Aug}$ & Vacant & - \\
\hline
\end{tabular}

For a description of habitat classes see Table 6. The areas of territories were determined by the method of S i ckel (1954). 


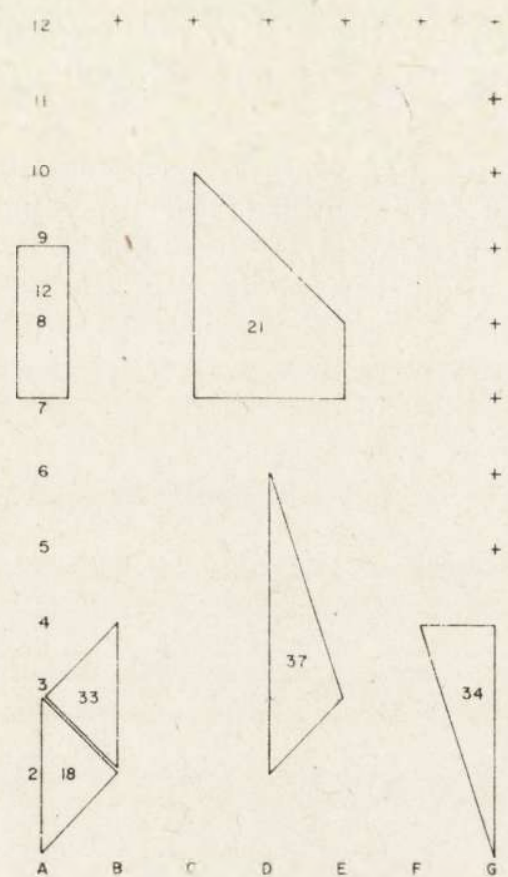

Fig. 11. Distribution of overwintered female territories during the 1974 breeding season. No areas of overlap exist. Numbers are those assigned to different individuals.

Table 6

Establishment of female territories.

\begin{tabular}{cccccc}
$\begin{array}{c}\text { Vole } \\
\text { Number }\end{array}$ & $\begin{array}{c}\text { Date of } \\
\text { first capture }\end{array}$ & $\begin{array}{c}\text { Cohort } \\
\text { of origin }\end{array}$ production & $\begin{array}{c}\text { Litter } \\
\text { Habitat } \\
\text { class }\end{array}$ & $\begin{array}{c}\text { Area of } \\
\text { territory }\left(\mathrm{m}^{2}\right)\end{array}$ \\
\hline 101 & 26 Jun & I & Yes & 2 & 562 \\
112 & 9 Jul & I & Yes & 2 & 675 \\
113 & 9 Jul & I & Yes & 1 & 225 \\
124 & 9 Jul & II & No & 3 & 112 \\
138 & 23 Jul & I & Yes & 2 & 225 \\
143 & 24 Jul & II & No & 2 & 112 \\
154 & 6 Aug & I & Yes & 2 & 112 \\
161 & 6 Aug & II & No & 1 & 337 \\
171 & 20 Aug & II & No & 2 & 337 \\
181 & 17 Sep & III & No & 5 & 450 \\
182 & 17 Sep & III & No & 3 & 112 \\
189 & 17 Sep & III & No & 3 & \\
198 & 1 Oct & III & No & 2 & \\
\hline
\end{tabular}

Voles were placed in a cohort on the basis of weight at first capture, by backdating and using a growth curve (Perrin, 1978). Cohort $I=v o l e s$ born before the end of May, II =voles born in June or the first two weeks of July, III =voles born after mid-July. Habitat classes were assigned on the density distribution of C. gapperi on the live-trapped grid (Fig. 13). Optimal habitats (1) were solely in areas of high density, good habitats (2) were predominantly in high density areas, average habitats (3) were those predominantly in areas of moderate density, poor habitats (4) were those predominantly in areas of low density, and unsuitable habitats (5) were those solely in areas of low density. The areas of territories were determined by the method of Stickel (1954). 
areas remained unoccupied. Generally, there were differences in spatial organization of the sexes during summer, which could have profound effects upon population density.

The establishment and size of territories may be correlated with the survival and density of overwintered territory holders, or with habitat (Table 5 and 6). Greatest numbers of voles were captured in areas of vegetation transition (Fig. 13), in the north where spruce gave way

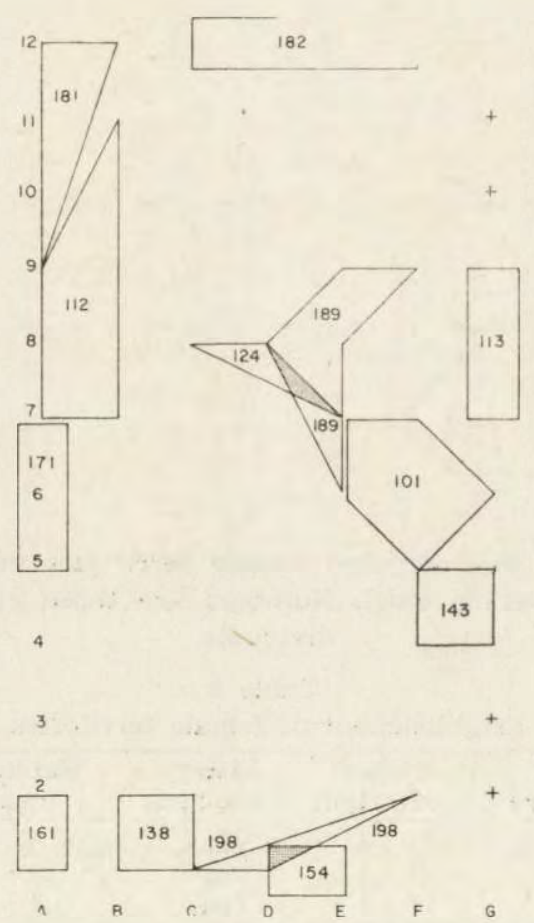

Fig. 12. Distribution of young female territories during the summer and autumn (from first capture until first snow-fall) of 1974. Areas of overlap are shaded. Numbers are those assigned to different individuals.

to birch and aspen, in the east adjacent old-field grassland, and in the west where drainage was poor. These ecotones contained a greater diversity of shrubs, herbs, grasses and sedges.

In 1973, snow cover was deep and was established early in November, but in 1974 a continuous deep snow cover was not formed until midDecember. Subnivean temperatures were lower from mid-November to mid-December in 1974 than 1973 and sudden declines in temperature were also more frequent in 1974 (Fig. 14). It is probable therefore that winter conditions were more extreme for C. gapperi in 1974 than in 1973. 


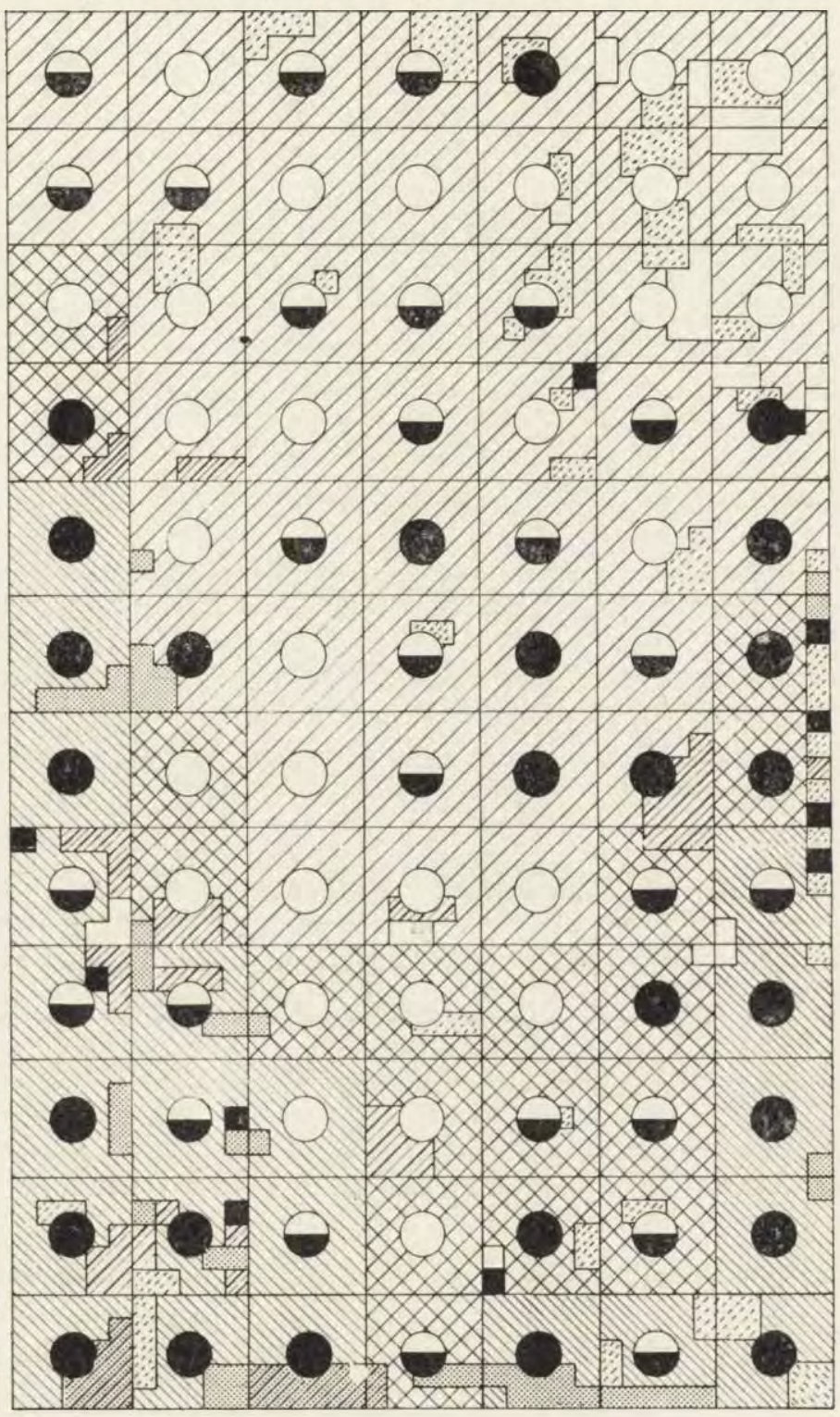

VEGETATION KEY

\begin{tabular}{|c|c|c|c|}
\hline$\square$ BIRCH & $\square$ LARCH & WILLOW & $\square$ MOUNTAIN MAPLE \\
\hline ER & BALSAM FIR & $\overline{\nabla A S H}$ & AND ALDE \\
\hline $\begin{array}{l}\text { SPHAGN } \\
\text { MIXED }\end{array}$ & AND LEDUM OR EC & ETUM & $\begin{array}{l}\text { VACCINIUM AND } \\
\text { CORNUS }\end{array}$ \\
\hline
\end{tabular}

Fig. 13. The vegetation and occurrence of $C$. gapperi on the live-trapped spruceforest grid. Black spruce was present in all areas.

C. gapperi distribution

$\mathrm{O}=$ low density ( 5 or fewer captures during the study).

$=$ medium density ( 6 to 10 captures during the study).

= high density (more than 10 captures during the study). 


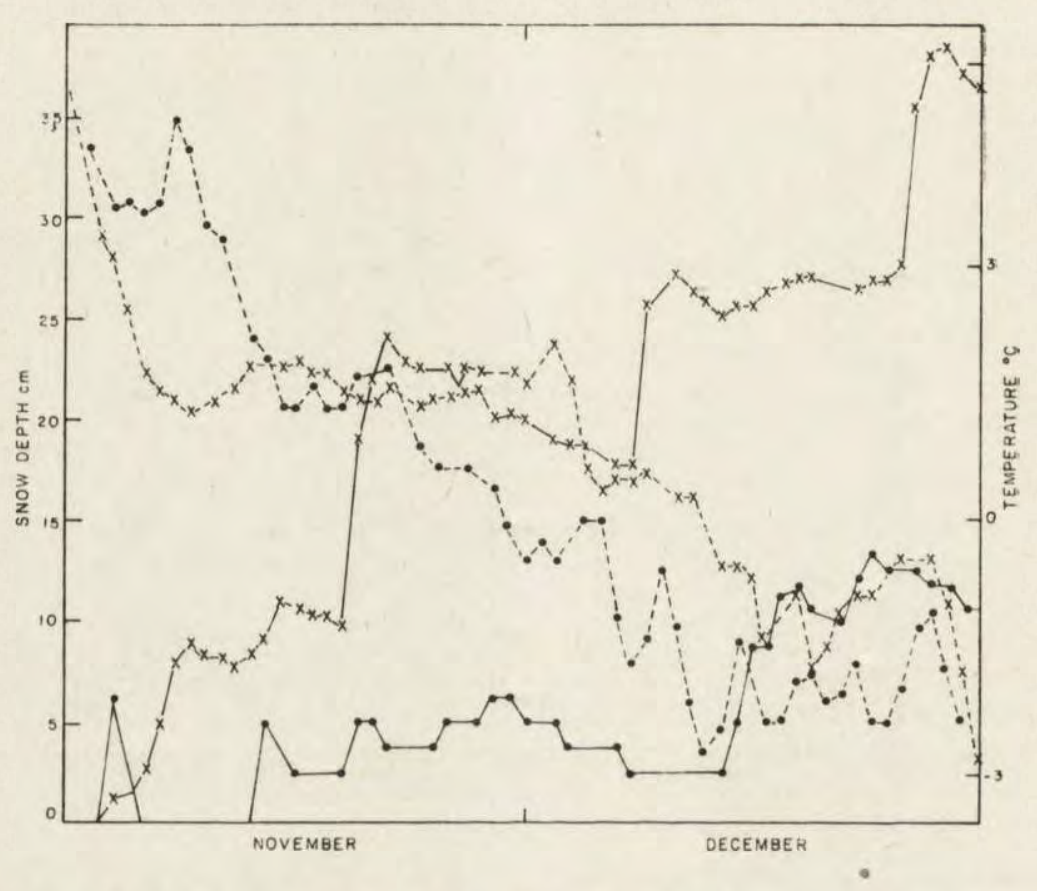

Fig. 14. Snow depth $(\longrightarrow$ ) and subnivean temperature $(-\longrightarrow$ (recorded at $5 \mathrm{~cm}$ beneath the soil surface) during November and December of $1973(\mathrm{X})$ and $1974(\cdot)$.

\section{DISCUSSION}

\subsection{General}

C. gapperi exhibits a four-year density cycle in Manitoba (I ve r s o n \& Turner, 1972, unpubl. data) and elsewhere in Canada (Fuller, 1969). The demographic data presented here were collected at the end of an increase year and during a peak year. A crash winter decline (type $M, \mathrm{Ch}$ itty, 1955) occurred at the end of the study in December 1974. Such declines are not common in Clethrionomys species but have been recorded previously $(\mathrm{Zejda}, 1967)$. Densities of $C$. gapperi in black spruce forest in Manitoba are comparable to those of C. glareolus in Bulgarian montane spruce forest ( $\mathrm{Markov}$ et al., 1972a) and of C. rutilus in white spruce forest in Alaska (Pruitt et al., 1960).

Variability in trappability can be a major problem in rodent population studies (P e r rin, 1975), but the probability of capture was high and fairly constant in this study due to high trap density in relation to rodent density, and to the use of permanent, baited trapping shelters (T an aka, 1970; Andrzejewski, Fejgin \& Liro, 1971). How- 
ever, since the weights of sub-adults at first capture were relatively high, and because of what is known of the timing of pregnancies, it appears that the initial capture of juveniles may have been delayed. Watts (1970) has shown that large male C. gapperi inhibit initial capture of juveniles.

\subsection{Reproduction}

C. gapperi males matured earlier in the year than females, although sexual maturation is controlled by daylength (Evernde $\mathrm{n} \& \mathrm{Fuller}$, 1972; R oth, 1974). All of the overwintered females and numerous: young females of the year produced litters. Overwintered males matured rapidly and some young males developed scrotal testes in the year of their birth. These young males may not have been sexually potent, as it was not known whether the accessory organs had developed ( $\mathrm{C}$ o u t t s \& R o w la nds, 1969). Mortality was also high in these voles, and hence it is probable that most females were inseminated by overwintered males.

Synchrony in the production of first litters probably resulted from the onset of reproduction being controlled by daylength ( $\mathrm{R} \circ \mathrm{t} h, 1974$; Evernden \& Fuller, 1972). Most second litters were born six weeks later, although the combined period of gestation and lactation in C. gapperi is 4.5 to 5.5 weeks (A s d e 11,1964 ; P e t e r s o n, 1966). However, in lactating $C$. glareolus pregnancy is prolonged by several days due to delay of implantation. A similar mechanism in C. gapperi might be important in explaining the interval between litters and the apparent inhibition of simultaneous pregnancy and lactation. Litters produced by young of the year must have resulted from conception at a very early age, and timing may be a direct result of the time required for sexual development. Synchrony in young production by overwintered and young females at the end of July was probably fortuitous. Typically female $C$. gapperi produced one litter during their first breeding season and two in the second, although an extra litter could be produced. Similar numbers of litters are produced by $C$. glareolus under natural ( $\mathrm{Z} \mathrm{e} \mathrm{j} \mathrm{d} \mathrm{a,} \mathrm{1966)} \mathrm{and} \mathrm{laboratory} \mathrm{(B} \mathrm{u} \mathrm{cha} \mathrm{lc} \mathrm{z} \mathrm{y} \mathrm{k,} \mathrm{1970)} \mathrm{conditions.} \mathrm{Only}$ first cohort females littered in the year of their birth which might indicate an inhibition of maturation in late cohort females $(B \mathrm{ujal} / \mathrm{ska}$, $1970,1973)$. However, the shortened breeding season may not have allowed time for second and third cohorts to mature relative to the period of increasing light (J e w e 11, 1966; S a d l e i r, 1969).

The distribution of births of C. gapperi during 1973 did not show a pattern as occurred during 1974, and the season appeared longer. 
This might have resulted from a longer breeding season and from litters being asynchronous, or alternatively, could have been caused by imperfect backdating. However, I vers o n \& T u rner (1976) have shown that the length of the breeding season of C. gapperi in Manitoba is in fact longer in increase and peak years than in decline and low density years. It therefore appears that the length of C. gapperi breeding season is related to population density or phase.

The value of litter size recorded here for C. gapperi is similar to the values published by F u ll e r (1969) and I vers o n \& T u r n e r (1976) for the same species, but higher than values for C. glareolus ( $\mathrm{Z} \mathrm{e} \mathrm{j} \mathrm{d} \mathrm{a,} \mathrm{1966;}$ Bujalska \& R yszkowski, 1966; Coutts \& R owlands, 1969). This might indicate that $C$. gapperi is more $r$-selected to increase productivity in areas with a restricted breeding season. Larger litters were produced by overwintered females than young of the years agreeing with observations of I vers on \& T u rner (1976). In C. gapperi litter size is correlated with body weight but not with age. Similar results have been presented for $C$. glareolus $(\mathrm{Z} \mathrm{e} \mathrm{j} \mathrm{d} \mathrm{a,} \mathrm{1966),} \mathrm{but} \mathrm{in} \mathrm{that} \mathrm{species}$ a seasonal change in litter size has been established.

\subsection{Age Structure and Survival}

Mortality was greatest in young voles during the breeding season. Of approximately 162 C. gapperi born on the live grid $98(60 \%)$ were ever trapped during the breeding season, indicating considerable $(40 \%)$ mortality prior to weaning and independence. Ivers on \& Turner (1976) have suggested a $5 \%$ loss of $C$. gapperi due to intra-uterine mortality, and $\mathrm{P}$ o p ov (1960) has stated that under field conditions postnatal mortality is $30 \%$ in C. glareolus. Survival of young voles may be affected by antagonism from adults ( $\mathrm{C} h$ it ty \& P h ip ps, 1966). Since levels of aggression in both sexes of $C$. gapperi during the breeding season were higher in adults than young ( $\mathrm{P}$ e r $\mathrm{r}$ in, in prep), survival of young $C$. gapperi may have been affected by aggression by adults. Changes in the survival and recruitment of young into natural murid populations have beeen explained by aggression ( $\mathrm{S}$ a d l e i r, 1965; $\mathrm{H}$ e ale y, 1967; W a t t s, 1969).

Changes in population age structure can be related to two previous hypotheses. Gliwicz (1975) has suggested that differences in winter age structure of $C$. glareolus are related to alternating changes in the viability and survival of early and late-born cohorts. The hypothesis is based on a suggested positive correlation between (1) the viability of young and the viability of their mothers, and (2) a young population age structure and good viability. Z e j d a (1967) has proposed a mecha- 
nism whereby the age structure of $C$. glareolus populations changes its cyclic phase. He has suggested that (1) the mean age of the overwintering population increases throughout the population cycle, (2) an increasing proportion of the offspring is produced by overwintering adults, and that (3) in the final year of the cycle, young are only born under narrowly defined conditions of environment and intraspecific relations. In C. gapperi in this study, (1) age was higher in the autumn of higher density year, (2) $70 \%$ of the offspring were produced by overwintered adults, and (3) the breeding season was slightly shorter at the higher density.

The older age structure of C. gapperi in 1974 agrees with the hypotheses of $\mathrm{Z} \mathrm{ejda} \mathrm{(1967)} \mathrm{and} \mathrm{G} \mathrm{liwicz} \mathrm{(1975),} \mathrm{in} \mathrm{that} \mathrm{an} \mathrm{older} \mathrm{winter}$ population followed a younger one. However, Z e j d a's (1967) hypothesis is not supported by the length of the C. gapperi (1974) breeding season since it was not greatly restricted. If the breeding seasons of 1973 and 1974 are regarded as being equivalent, the observed difference in autumn age structure would have resulted from differences in cohort survival between years as postulated by G li w i c z (1975), but this cannot be demonstrated precisely. It is suggested that the survivorship and reproductive capabilities of each cohort may vary with population density and levels of aggression ( $\mathrm{P}$ er rin, in prep), but more detailed information is required.

Higher survival of adult C. gapperi in winter (1973/4) than summer (1974) has also been observed in other Clethrionomys species ( $\mathrm{P}$ e tr usewicz et al., 1968, Newson, 1963; Bujalska, 1975; Gliwicz et al., 1968).

\subsection{Movements and Distribution}

Significant seasonal differences in home range size were not observed in this study. Similar observations have been made by Merritt \& $\mathrm{N}$ ol a n (1974). No significant sex differences in home range area were observed although numerous authors (B e r g s t e d t, 1966; R a d d a et al., 1967; $\mathrm{R}$ add a, 1968; Mazurkiewicz, 1971; Andrzejew$\mathrm{sk}$ i et al., 1967) have demonstrated larger ranges in males than females, with greatest disparity in winter ( $\mathrm{r}$ ow $\mathrm{n}, 1956$; M a z u kiewicz, 1971; R a d d a, 1968).

Shifts occurred in the home ranges of male $C$. gapperi at snow-melt and were temporally associated with the onset of increased agressiveness (P e r r in, in prep). Similar shifts have been reported by M e rritt \& Nolan (1974), Rad d a (1968), and M a z urkiewicz (1971), 
and may function in maintaining genetic diversity in the population (G a r t e n \& S m ith, 1974; S mith et al., 1972).

Young female C. gapperi tended to occupy areas unoccupied by overwintered females first while areas vacated due to mortality of adult females were colonized later. Adult aggression ( $\mathrm{P}$ e r r in in prep) may have adversely affected juvenile settlement in C. gapperi, as occurs in C. glareolus (Kołodziej et al., 1973; Mazurkiewicz, 1971). Indeed, P o w e 11 (1972) has suggested that juvenile C. gapperi are forced into sub-optimal habitats by adults, which agrees with current findings. Aggression may therefore function to space out individuals, and to initiate dispersal and the colonization of new habitats. However, low levels of interspecific aggression during winter may also be important in allowing for colonization of new habitats (T u rner et al., 1975).

Breeding adult female $C$. gapperi were territorial during summer, but this territoriality ceased in winter, as occurs in C. glareolus $(\mathrm{B} \mathrm{u} \mathrm{ja} \mathrm{l-}$ sk a, 1970, 1971, 1973). Following the death of overwintered females, young females established territories which were smaller than those of adults in late spring. However, during summer the number of territories had doubled, density had increased, and aggression was still high (P e r rin in prep). Therefore, it seems likely that territory size decreased because of social pressure from increased density.

$\mathrm{Bujalska}$ (1971) regards the territoriality of female C. alareolus to be the basis of mechanism which limits population increase by regulating the number of females capable of reproduction. In order to demonstrate that a population is regulated by a behavioural mechanism, such as territoriality, several conditions must be satisfied (W a t s o n \& Moss, 1970). Firstly, it must be demonstrated that part of the population does not breed, but that these non-breeders are physiologically capable of breeding. Secondly, it must be shown that the breeding population does not exhaust any specific resource, e.g., space or food. No definite conclusions can be drawn for C. gapperi but some observations are recorded.

The whole population did not breed, although all overwintered males became sexually mature and all adult females littered. Only some young males developed scrotal testes, and only first cohort females produced litters. Whether these non-breeders were capable of breeding is not known. When second and third cohorts established territories, the breeding season was well advanced and daylength was decreasing, which may have prevented successful mating. However, aggression was high in females ( $\mathrm{P}$ e r r in in prep) and might have influenced the development and fertility of second and third cohorts. Females of the year only produced litters after the death of overwintered breeding females. This 
might suggest that non-breeders became physiologically capable of reproduction as population structure changed. Alternatively physiological activity might have occurred in young females in the presence of overwintered females, if the latter had survived.

It appears unlikely that space was limiting, since territorial females occupied only a relatively small part of the study area. Food availability in terms of rodent requirements was not assessed and neither was cover. It is thus evident that more research is required to examine resource utilization by $C$. gapperi and to test the conditions for behavioural population regulation specified by W a t s o n \& M o s s (1970).

\subsection{Climate and Winter Survival}

Extreme climatic conditions are known to cause declines in the density of northern Clethrionomys population (F u lle r, 1967; E 11 i ot t, 1969; Whitney, 1973). The critical periods for survival occur in spring and autumn and are associated with the formation and thawing of a stable insulating snow cover, and extreme temperatures at these times (F u 11e r, 1969).

During the winter of $1974 / 5$, C. gapperi numbers declined rapidly, although they had been stable the previous winter. This loss is interpreted as mortality because mass dispersal appears unlikely from optimal habitat in mid-winter when density and the intensity of aggression were low, and since during the previous winter there had been no significant emigration. In November and December 1974, when mortality took place, the diet was equivalent to that of the previous year. but some differences were evident in body composition ( $\mathrm{Per}$ rin in press). Fat contents were reduced to minimal levels, protein was lost and mineral content increased. This was indicative of leaner voles and possible protein breakdown and utilization. The observed mortality was associated with periods of thin and transient snow cover, and these harsh climatic conditions may have affected feeding behaviour and body composition, and contributed to the mortality. $\mathrm{K}$ a 1 e la (1957) has suggested that winter food shortages may be involved in the local declines of C. rufocanus, which is supported by A ula k's (1973) work on C. glareolus. It is therefore suggested that in C. gapperi, the combined effects of extreme climatic conditions and changes in feeding interacted to cause the observed mortality. The method of operation of these mortality factors is not known, but it is hypothesized that poor snow cover may expose nests to severe temperatures, reduce activity and cause surface food plants to freeze. This may affect feeding behaviour, and the availability and quality of food plants at a time when energy demands for 
thermoregulation are high. However, it is not suggested that food is the sole factor controlling winter mortality, and Andrzejewski (1975) has shown that increasing food supplies to $C$. glareolus does not lead to increased survival. More research is required on the winter ecology of northern rodents, particularly in relation to climate, microenvironments, and food availability and quality under subnivean conditions.

\section{CONCLUSION}

There was a seasonal fluctuation in the density of C. gapperi and numbers peaked at the end of the breeding season. Winter survival was greater than that of the summertime breeding season, except extreme climatic factors operated. High survivorship in winter may have been due to the cessation of growth, reproduction and intense aggression. The breeding season was short but intensive in that all overwintered and most first cohort females littered. Second and third cohort females did not breed, either due to a shortage of time for maturation in relation to daylength or because of adult antagonism and territoriality. Litter size was large and juvenile mortality was heavy which is indicative of $r$-selection. Juvenile mortality was temporally associated with maximal levels of aggression and in the peak density year the population age structure was younger suggesting recruitment from late-born cohorts. Home range sizes were similar for both sexes and seasons but probably functioned differently for each sex during the breeding season. Males exhibited more range shifts and long-distance movements, which may be associated with genetic exchange, whereas adult females occupied territories that might function in population regulation. An extreme autumn climate with poor snow cover and low subnivean temperatures caused severe mortality either directly, or indirectly, by disturbing foraging or food quality and consequently body composition, which may have led to starvation or increased predation. Finally, it is tentatively suggested that the natural regulation of $C$. gapperi is based on spacing behaviour through aggression, with weather as an ancillary limiting factor, and food supply as the ultimate controlling factor.

Acknowledgements: I wish to express my gratitude, thanks and appreciation for the help that I have received from the members of staff of the Environmental Research Branch, Whiteshell Nuclear Research Establishment, Pinawa, Manitoba, and in particular to Dr. S. L. Iverson for making the study possible. The project was conducted whilst I was in receipt of a National Research Council of Canada Postdoctoral Research Fellowship, and was financed by Atomic Energy of Canada Limited. 


\section{REFERENCES}

1. Andrzejewski R., 1975: Supplementary food and the winter dynamics of bank vole populations. Acta theriol., 20: 23-40.

2. Andrzejewski R., PetrusewiczK. \& Waszkiewicz-Gliwicz J., 1967: The trappability of Clethrionomys glareolus (S chreber, 1780) and other ecological parameters obtained by the CMR capture method. Ekol. Pol. A., 15: $710-725$.

3. Andrzejewski R., Fejgin H. \& Liro A., 1971: Trappability of trapprone and trap-shy bank voles. Acta theriol., 17: 41-56.

4. Asde11 S. A., 1964: Patterns of Mammalian Reproduction. Constable: $1-670$. London.

5. A lak W., 1973: Production and energy requirements in a population of the bank vole in a deciduous forest of Circaeo-Alnetum type. Acta theriol., 18: $167-190$.

6. Bergstetdt B., 1966: Home ranges and movements of the rodent species Clethrionomys glareolus (Schreber), Apodemus flavicollis (Melchior) and Apodemus sylvaticus (Linne) in southern Sweden. Oikos, 17: 150-157.

7. Brown L. E., 1956: Movements of some British small mammals. J. Anim Ecol., 25: 54-71.

8. B u chalczyk A., 1970: Reproduction, mortality and longevity of the bank vole under laboratory conditions. Acta theriol., 15: 153-176.

9. Buja 1ska G., 1970: Reproduction stabilizing elements in an island population of Clethrionomys glareolus (S chreber, 1780). Acta theriol., 15: 381412.

10. Buja lska G., 1971: Self-regulation of reproduction in an island population of Clethrionomys glareolus (S chre be r, 1780). Ann. Zool. Fenn., 8: 91-93.

11. Bujalska G., 1973: The role of spacing behaviour among females in the regulation of reproduction in the bank vole J. Reprod. Fert., Suppl., 19: $465-474$.

12. Bujalska G., 1975: Reproduction and mortality of bank voles and the changes in the size of an island population. Acta theriol., 20: 41-56.

13. Bujalska G. \& R y skowski L., 1966: Estimation of the reproduction of the bank vole under field conditions. Acta theriol., 11: 351-361.

14. Butsch R. S., 1954: The life history and ecology of the redbacked vole, Clethrionomys gapperi Vigors in Minnesota. Ph. D. Thesis, Univ. of Michigan.

15. Chitty D., 1955: Adverse effects of population density upon the viability of later generations. [In: "The Numbers of Man and Animals«, J. B. Cragg and N. W. Pirie, Eds.]. 57-67. Edinburgh.

16. Chitty D. \& Phipps E., 1966: Seasonal changes in survival in mixed populations of two species of vole. J. Anim. Ecol,, 35: 313-331.

17. Coutts R. R. \& Rowlands I. W., 1969: The reproductive cycle of the Skcmer vole (Clethrionomys glareolus skomerensis). J. Zool., Lond., 158: 1-25.

18. D a vis D. E., 1956: Manual for analysis of rodent populations. Penn. State Univ Press: $1-82$.

19. Eljiott P. W., 1969: Dynamics and regulation of a Clethrionomys population in Central Alberta. Ph. D. Thesis, Univ. of Alberta.

20. Evernden L. N. \& Fuller W. A., 1972: Light alteration caused by snow and its importance to subnivean rodents. Can. J. Zool., 40: 1023-1032. 
21. Fuller W. A., 1967: Ecologie hivernale des lemmings et fluctuations de leurs populations. Terre Vie, 114: 97-115.

22. Fuller W. A., 1969: Changes in numbers of three species of small rodent near Great Slave Lake, N. W. T. Canada, 1964-1967, and their significance for general population theory. Ann. Zool. Fenn., 6: 113-144.

23. Garten C. T. \& S mith M. H., 1974: Movement of oldfield mice and population regulation. Acta theriol., 19: 513-514.

24. Gl:wicz J., 1975: Age structure and dynamics of numbers in an island population of bank voles. Acta theriol., 20: 57-69.

25. Gliwicz J., Andrzejewski R., Bujalska G. \& PetrusewiczK., 1968: Productivity investigation of an island population of Clethrionomys glareolus (S c hre ber, 1780). I. Dynamics of cohorts. Acta theriol., 13: 401-413.

26. Healey M. C., 1967: Aggression and self-regulation of population fluctuations of voles (Microtus). Ecology, 48: 377-392.

27. Ivers on S. L. \& Turner B. N., 1969: Undet-snow shelter for small mammal trapping. J. Wild. Mgmt. 38: 722-723.

28. Iverson S. L. \& T urner B. N., 1972: Winter coexistence of Clethrionomys gapperi and Microtus pennsylvanicus in a grassland habitat. Amer. Midl. Nat. 88: $440-445$.

29. Ivers on S. L. \& T urner B. N., 1976: Small mammal radioecology: natural reproductive patterns of seven species. Atomic Energy of Canada Limited report AECL-5393.

30. Jewe 11 P. A., 1966: Breeding season and recruitment in some British mammals confined on small islands. Symp. Zool. Soc. Lond., 15: 89-116.

31. Kalkusalo A., 1972: Population turnover and wintering of the bank vole Clethrionomys glareolus ( $\mathrm{Schreb}$ ), in southern and central Finland. Ann. Zool. Fenn., 9: 219-224.

32. Kalela O., 1957: Regulation of reproduction rate in subarctic populations of the vole Clethrionomys rufocanus (S u n d.). Ann. Acad. Sci. Fenn., Ser. A. IV, $34: 1-60$.

33. Kolodziej A., Pomianowska I. \& Rajska E., 1973: Differentiation of contacts between specimens in a Clethrionomys glareolus population. Bull. Acad. Pol. Sci., 20: 97-102.

34. Koshkina T. V., 1965: Population density and its importance in regulating the abundance of the red vole. Bull. Mosc. Soc. Nat., Biol. Sect., 70: 5-19.

35. Markov G., Christov L. \& Gliwicz J., 1972a: A population of Clethrionomys glareolus pirinus on the Vitosha Mountain, Bulgaria. I. Variations in numbers and age structure. Acta theriol., 17: 327-335.

36. Markov G., Bujalska G. \& Christov L., 1972b: A population of Clethrionomys glareolus pirinus on the Vitosha Mountain, Bulgaria. II. Natality. Acta theriol., 17: $337-342$.

37. Mazurkiewicz M., 1971: Shape, size and distribution of home ranges of Clethrionomys glareolus (S chreber, 1780). Acta theriol., 16: 23-60.

38. Merritt J. F. \& Nolan J., 1974: Subnivean home ranges of the red-backed vole. Clethrionomys gapperi, in Colorado subalpine forest. Paper presented at 54th annual meeting of the American Society of Mammalogists, Binghampton, N. Y. June 1974.

39. N e v s on R., 1963: Differences in numbers, reproduction and survival between two neighbouring populations of bank voles (Clethrionomys glareolus). Ecology, 44: $110-120$. 
40. Perrin M. R., 1975: Trap deaths. Acta theriol., 20: 167-174.

41. Perrin M. R., 1978: Molar root-length as an indicator of age in Clethrionomys gapperi. Acta theriol., 23: 423-434.

42. Perrin M. R., 1979: Seasonal variation in the body composition and diet of Clethrionomys gapperi in spruce forest. Acta theriol., 24: 299-318.

43. Perrin M. R., (in prep): The annual cycle of aggression of Clethrionomys gapperi in southeastern Manitoba.

44. Peterson R. L., 1966: The Mammals of Eastern Canada. Oxford Univ. Press. Toronto.

45. Petrusewicz K., Andrzejewski R., Bujalska G. \& Gliwicz J., 1968. The role of spring, summer and autumn generations in the productivity of a free-living population of Clethrionomys glareolus ( $\mathrm{S} \mathrm{chreber}, 1780$ ). [In: "Energy Flow Through Small Mammal Populations«, K. Petrusewicz, and L. Ryszkowski, Eds.]. Państw. Wyd. Nauk: 235-245. Warszawa.

46. P o p o v V. A., 1960: Mlekopitajuščie Volžko-Kamskogo Kraja. Akad. Nauk SSSR: $1-468$. Kazan.

47. P owe 11 R. A., 1972: A comparison of populations of boreal red-backed vole (Clethrionomys gapperi) in tornado blown and standing forest. J. Mammal., 86: 377-379.

48. Pruitt W. O., 1968: Synchronous biomass fluctuations of some northern mammals. Mammalia, 32: 172-191.

49. Pruitt W. O., Jr., Lent P. C. \& Murray B., 1960: Ogotoruk Valley mammal investigations. (Interim. Final Rep) Univ. of Alaska.

50. R ad d a A., 1968: Populations Studien an Rötelmausen (Clethrionomys glareolus Schreber, 1780) durch Markierungefang in Niederösterreich. Oecologia (Berl.) 1: 219-235.

51. Radda A., Kunz C., Loew J., Neumann A., Pretzmann G. \& Zukrigl K., 1967: Beitrag zur Kenntnis der Synökologie des Virus der Zentraleuropäischen Encephalitis. Zbl. Bakt., I. Abt. Orig., 202: 273-296.

52. Roth R. R., 1974: The effect of temperature and light combinations upon the gonads of male red-backed voles. Biol. Reprod., 10: 309-314.

53. S a uleir R. M. F. S., 1965: The relationship between agonistic behaviour and population changes in the deermouse, Peromyscus maniculatus (W a g n e r). J. Anim. Ecol, 34: 331-352.

54. S a dleir R. M. F. S., 1969: The Ecology of Reproduction in Wild and Domestic Mammals. Methuen: $1-321$. London.

55. Smith M. H., Carmon J. L. \& Gentry J. B., 1972: Pelage color polymorphism in Peromyscus polionotus. J. Mammal., 53: 824-833.

56. Stickel J. F., 1954: A comparison of certain methods of measuring ranges of small mammals. J. Mammal., 35: 1-15.

57. Tanaka R., 1970: A field study of the effect of prebaiting on censusing by the capture-recapture method in a vole population. Res. Popul. Ecol., 12: $111-125$.

58. Turner B. N., Perrin M. R. \& I vers on S. L., 1975: Winter coexistence of voles in spruce forest: relevance of seasonal changes in aggression. Can J. Zool., 53: $1004-1011$.

59. Wats on A., \& Moss R., 1970: Dominance, spacing behaviour and aggression in relation to population limitation in vertebrates. [In: "Animal Population in Relation to their Food Resources«, A. Watson, Ed.]. Blackwell: 167-220 Oxford. 
60. W att s C. H. S., 1969: The regulation of wood mouse (Apodemus sylvaticus) numbers in Wytham Woods, Berkshire. J. Anim. Ecol., 38: 285-304.

61. Watts C. H. S., 1970: A field experiment in intraspecific interactions in the red-backed vole, Clethrionomys gapperi. J. Mammal., 51: 341-347.

62. Whitney P. H., 1973: Population biology and energetics of three species of small mammals in the taiga of interior Alaska. Ph. D. Thesis, Univ. of Alaska. pp. 254.

63. Zejda J., 1961: Age structure in population of the bank vole, Clethrionomys glareolus S chre ber, 1780. Zool. Listy., 10: 249-264.

64. Z e ida J., 1964: Development of several populations of the bank vole Clethricnomys glareolus S chreb., in a peak year. Zool. Listy., 13: 15-30.

65. Zejda J., 1966: Litter size in Clethrionomys glareolus $\mathrm{S}$ chre be r, 1780. Zool. Listy., 15: 193-206.

66. Zejda J., 1967: Mortality of a population of Clethrionomys glareolus $\mathrm{S} \mathrm{chre} \mathrm{b.} \mathrm{in} \mathrm{a} \mathrm{bottomland} \mathrm{forest} \mathrm{in} \mathrm{1964.} \mathrm{Zool.} \mathrm{Listy.,} \mathrm{16:} \mathrm{221-238.}$

Accepted, May 15, 1979.

M. R. PERRIN

\section{ROLA ROZRODU, PRZEŻYWANIA I TERYTORIALIZMU W SEZONOWEJ DYNAMICE POPULACJI CLETHRIONOMYS GAPPERI}

Obiektem badań były populacje Clethrionomys gapperi (V i g or s, 1830), zamieszkujące lasy iglaste (Picea mariana) w południowo-wschodniej Manitobie (Ryc. 1). Badano rozmnażanie, przeżywanie i terytorializm w zależności od dynamiki sezonowej rornic (Ryc. 2). Szczyt zagęszczenia wystąpił w 1974 r. po fazie wzrostu populacii w 1973 r. Zimą 1974/5 nastąpiło załamanie lub też spadek liczebności typu $M$, które towarzyszyło ekstremalnym warunkom klimatycznym. Samice-przezimki produkują około $70 \%$ miotów w czasie sezonu rozrodu. W ciągu roku swego urodzenia dają mioty tylko samice $\mathrm{z}$ pierwszej kohorty (Tabela 1). Ukazanie się pierwszych miotów było zsynchronizowane prawdopodobnie z długością dnia, a çrugi szczyt w produkcji miotów wystąpił pod koniec lata (Ryc. 5). Wielkość miotów była duża, co mogło stanowić adaptację do wzrastającej produktywności zwlaszcza, że sezon rozrodu był krótki. Wydaje się, że sezon ten jest dłuższy w fazie wzrostu populacji, niż w fazie szczytu; nie obserwowano rozrodu zimowego. Przeżywalność zimowa w 1973/4 przewyższała przeżywalność w sezonie rozrodu 1974, a samce-przezimki żyły dłużej niż samice-przezimki w czasie sezonu rozrodu (Ryc. 7). Przeżywalność młodych była niska a samce przeżywały gorzej niż samice lecz nie było wielkich różnic w przeżywaniu między kohortamj w 1974 r. (Ryc. 8, 9, 10). Brak było istotnych różnic w wielkości areału osobniczego między osobnikami różnej płci i między sezonami (Tabela 3, Ryc. 11). Samice zajmują wyłączne terytoria w lecie, natomiast samce posiadają zachodzące na siebie areały, których centrum przesuwa się po stajaniu śniegu (Tabela 4). Osiedlanie się młodych samic na terytorium populacji zależy prawdopodobnie od długości życia przezimowanych samic, zagęszezenia populacji i właściwości środowiska (Tabele 5, 6; Ryc. 12). Autor sugeruje, że naturalna regulacja populacji u C. gapperi jest oparta na behawiorze przestrzennym i agresywności oraz na dwóch czynnikach limitujących: pierwszym i głównym są zapasy pokarmowe (Ryc. 13) a drugim, dodatkowym jest pogoida (Ryc. 14). 